\title{
Sedimentological Characterization Of Subsurface Formations Of The Tertiary - Quaternary In The Dabou Region (South Of Ivory Coast)
}

\author{
Gbangbot Jean-Michel Kouadio, N'Doufou Gnosseith Huberson Claver, Saimon Aby Atsé Mathurin
}

\begin{abstract}
About 239 samples of cuttings from two boreholes located in Dabou were the subject of sedimentological studies (lithological, granulometric and morphoscopic analysis) in this work. These studies aim to identify the origin of these sediments and to specify the factors and the phenomena which involved in their transport and their deposit during Tertiary - Quaternary. After a detailed lithological description of each sample, the sandy fractions were treated according to conventional particle size methods. The formations traversed in the two wells consist of lateritic clays, yellow clays, clay sands and coarse sands. The analyzed sands are coarse and testify to the différents variations in the energy of the stream that transported the sediments. The hyperbolic granulometric facies is dominant in the study area, indicating a variation in streamflow during sedimentation. The predominantly round to sub-round quartz grains suggest a relatively distal supply source while their blunted blunted appearance suggests a stay in the aquatic environment. The sediments of these two wells are therefore sands of fluviatile origin, deposited in a shallow marine environment.
\end{abstract}

Index Terms - Dabou, sedimentology, tertiary - quaternary, facies

\section{INTRODUCTION}

Water is the most exploited natural resource in the world. It remains the most important commodity and of great human consumption. Access to safe drinking water in the world is a major problem, unresolved in many countries, and often linked to poverty.

Despite the abundance of water on the planet, the amount of fresh water available is a tiny fraction. Today, it is receiving a lot of attention because water is becoming increasingly scarce. The drilling project in the Dabou region has been set up to meet household and industrial needs for drinking water. These boreholes not only make it possible to cope with the ever-increasing needs for water, but also provide access to lithological,micropaleontological, palynological and hydrogeological approaches [1]. Some author such as [2], allowed to make a revision of the geology of the west of the onshore basin Ivorian. East of the onshore

Gbangbot Jean-Michel Kouadio, University Jean Lorougnon Guédé, UFR Environment BP 150 Daloa Ivory Coast

N'Doufou Gnosseith Huberson Claver, University Peleforo Gon Coulibaly, UFR Biological Sciences, BP 1328 Korhogo Ivory Coast

Saimon Aby Atsé Mathurin, Ocean Research Center, Laboratory of Physics and Marine Geology (Phygem), BP V18 Abidjan, Ivory Coast basin is also known from the work of [3] - [4] - [5] - [6] - [7] [1] - [8] - [9] - [10], based on outcrops and drill cuttings at Alépé, Bingerville, Samo, Adiaké, Eboinda, Assinie, Adjamé, Bonoua, Aboisso and Yopougon. The aim of these studies was to specify the lithostratigraphic characteristics of the formations encountered, their origin, and the factors and phenomena involved in sediment transport and deposition. The data on this part of the Dabou basin are scarce, like some works available in literature, [11] which worked on the quantitative and qualitative aspect of the groundwater of Dabou and [12] which worked on the characteristicshydrodynamics of these aquifers. It is in this context that the present study, "Sedimentological Characterization of Subsurface formations of the Tertiary-Quaternary in the Dabou Region (South Ivory Coast)," is in addition to earlier research, to give a scientific overview on the current state of the geology of the Dabou region with the objective of highlighting the nature of the formations crossed by the various boreholes. Its interest is to better know the geology of the region of Dabou thus facilitating the search for potential resources.

\section{PRESENTATION OF THE STUDY AREA}

Located in the south of Ivory Coast, west of Abidjan, the Dabou region covers an area of $1290 \mathrm{~km}^{2}$ and lies between longitudes $4^{\circ} 16^{\prime}$ and $4^{\circ} 60^{\prime}$ West and latitudes $5^{\circ} 07^{\prime}$ and $5^{\circ} 33^{\prime}$ North. This region is limited to the north by the sedimentarybasement contact, to the east by the Agnéby and to the west by the Bandama. The Dabou region has two distinct geological assemblages: the basement formations largely represented by schists with some granites and sedimentary basin formations. The study area belongs to the bridge area. The different water holes were drilled in two localities namely Pakidié (121 m) and Toupah $(118 \mathrm{~m})$, whose geographical coordinates are given in Table 1

Table 1: Location of Drilling

\begin{tabular}{llll}
\hline Locality & $\begin{array}{l}\text { Longitude } \\
(\mathbf{W})\end{array}$ & $\begin{array}{l}\text { Latitude } \\
(\mathbf{N})\end{array}$ & Well (P) \\
\hline Dabou & $04^{\circ} 23^{\prime} 43.3^{\prime \prime}$ & $05^{\circ} 18^{\prime} 31.3^{\prime \prime}$ & Pakidie (P1) \\
\hline Dabou & $04^{\circ} 34^{\prime} 51.8^{\prime \prime}$ & $05^{\circ} 19^{\prime} 42.8^{\prime \prime}$ & Toupah (P2)
\end{tabular}



(South Of Ivory Coast)
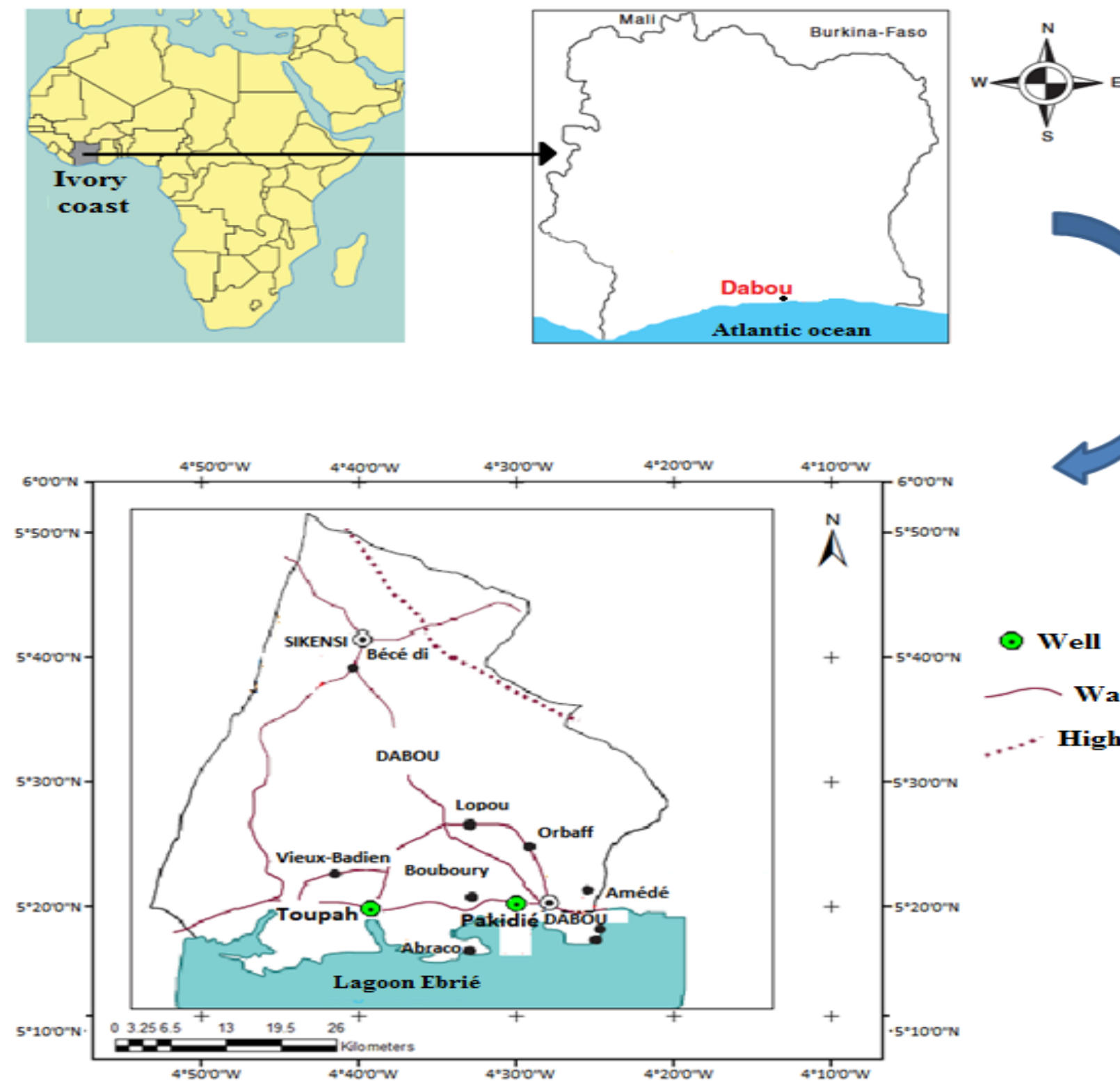

$\odot$ Well

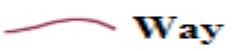

.... Highway

Figure 1: Geographical location of executed boreholes

\section{MATERIALS AND METHODS}

The material used to support this study consists essentially of 239 samples of water cuttings made by FORACO (Drilling Rational Construction). Their analysis focused on the lithological description, the granulometry of the sandy fractions and the morphoscopy of the quartz grains. The lithological analysis (macroscopic description and washing residues) made it possible to assess the relative abundance of the figured elements. The particle size analysis whose objective is to measure grain size and to know the statistical frequency of the different sizes was carried out on a column of 16 sieves (AFNOR) according to the classical procedure adopted in the recent work of [13]. The different parameters (mean, standard deviation and skewness) have been interpreted according to the laws of sedimentological analysis adopted by many authors [14] - [15] - [16] - [17] - [18] - [19]. The morphoscopic study of quartz grains carried out using the Scanning Electron Microscope (SEM) provides information on sediment wear and the nature of the transport agent.

\section{RESULTS}

-Lithological of the Toupah well

This well is characterized by three facies (lateritic clays, yellow clays and coarse sands) which appear as follows: (i) laterite clays ( 3 to $13 \mathrm{~m}$ ) with rare grains of pyrite and carbonaceous debris, (ii) coarse sands and coarse clay sands (13 to $78 \mathrm{~m}$ ); (iii) yellow clays (78 to $91 \mathrm{~m}$ ); (iv) sandy clays (91 to $96 \mathrm{~m}$ ) and (v) coarse sands (96 to $118 \mathrm{~m}$ ).

\section{- Lithological of the Pakidie well}

The lithology of the Pakidie well shows in the drilling direction three facies as well (lateritic clays, yellow clays and coarse sands). These are: (i) laterite clays (3 to $17 \mathrm{~m}$ ) with rare grains of pyrite and carbonaceous debris; (ii) coarse sands and coarse clay sands (17 to $90 \mathrm{~m}$ ); (iii) yellow clays (90 to $98 \mathrm{~m}$ ); (iv) coarse sands (98 to $96 \mathrm{~m}$ ) and (v) yellow clays (117 to $121 \mathrm{~m})$.

\section{- Lithological correlation}

Correlations are, by definition, equivalences that can be established between geologic layers and are based on

similarities in lithology, fossiliferous content, or logging characteristics. For the present study, only lithology has been 
taken into account. The correlation of the lithological logs of the Pakidie and Toupah wells made it possible to identify five (5) lithological units which are:

(i) unit 1 , consisting of yellow clays ( $3 \mathrm{~m}$ ) is only present in the Pakidie well;

(ii) unit 2, consisting of coarse sands. These sands have a thickness of $21 \mathrm{~m}$ in the Toupah well and a thickness of $19 \mathrm{~m}$ in the Pakidie well;

(iii) unit 3 , consisting of yellow clays and sandy clays. Its thickness is $12 \mathrm{~m}$ in the Toupah well and $8 \mathrm{~m}$ in the Pakidie well;

(iv) unit 4, consisting of alternating coarse sands and clay sands. This unit has a thickness of $73 \mathrm{~m}$ in the Pakidie well and $66 \mathrm{~m}$ in the Toupah well;

(v) unit 5, consisting of laterite clays of orange-yellow color. This unit has a thickness of $15 \mathrm{~m}$ in the Pakidie well and $12 \mathrm{~m}$ in the Toupah well.

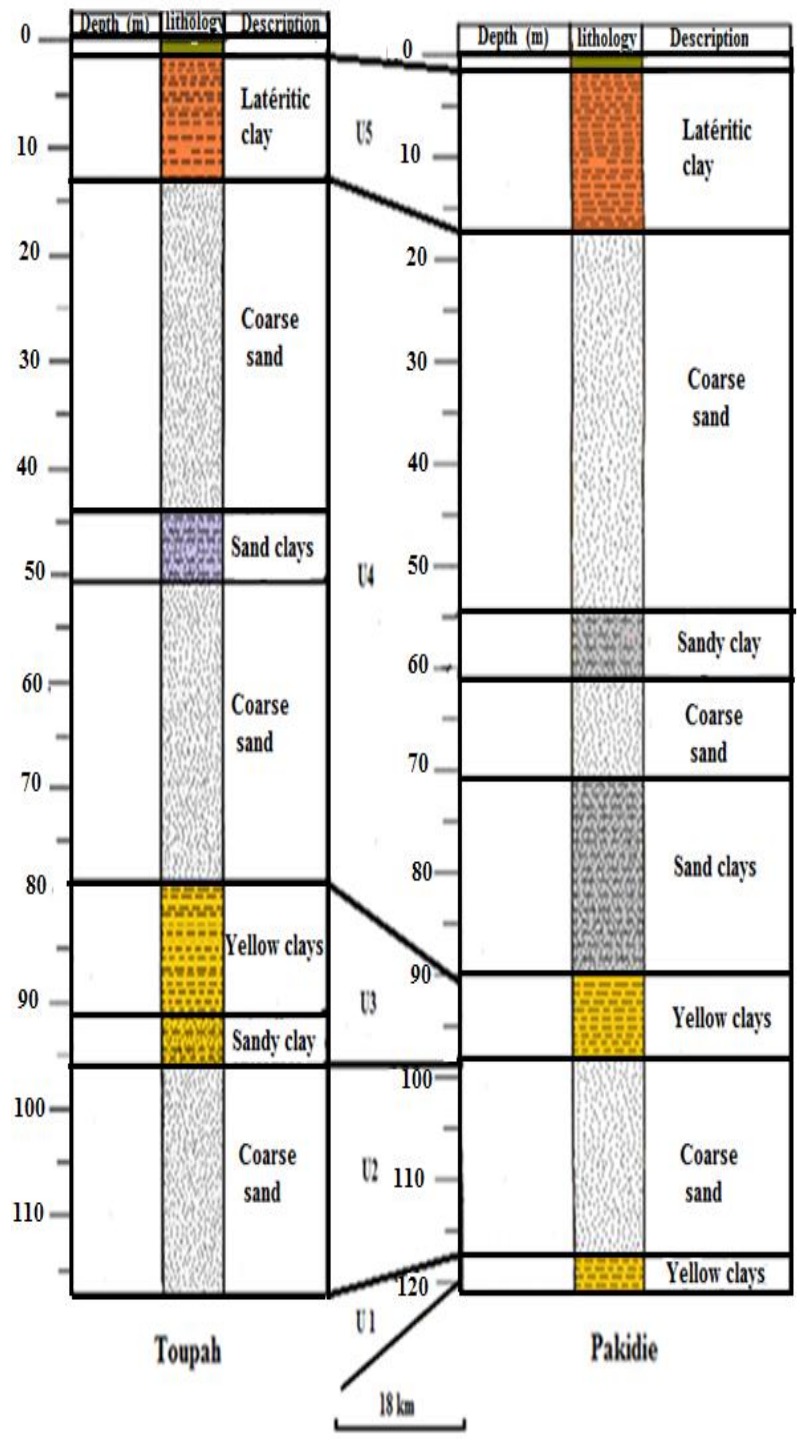

Figure 2: Lithological synthesis of the Toupah and Pakidié wells

\section{- Granulometric facies}

The cumulative semi-logarithmic curves of the Toupah and Pakidie sands present mostly a sigmoid-like appearance. This is the deposition facies by excess of charge. This facies indicates a gradual reduction of the transport agent.

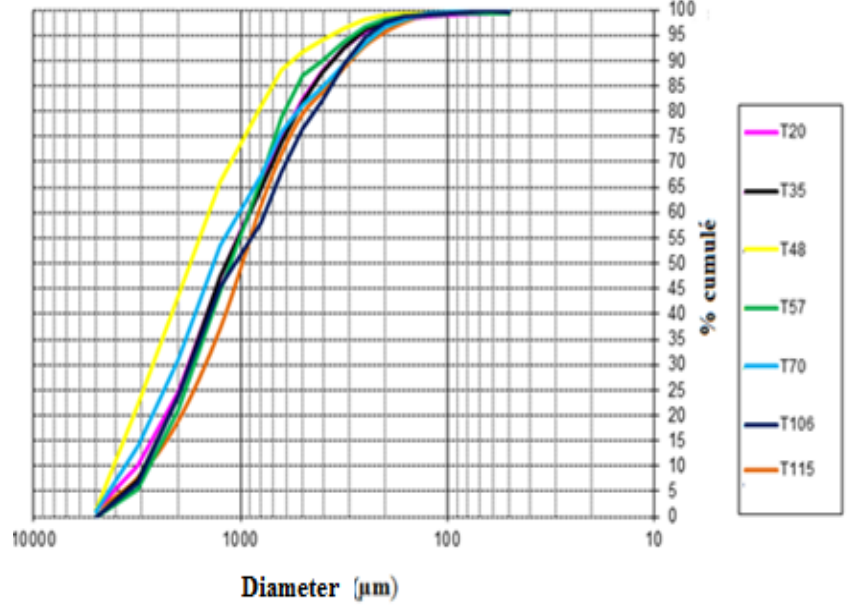

Figure 3: Semi-log cumulative curves of Toupah sands

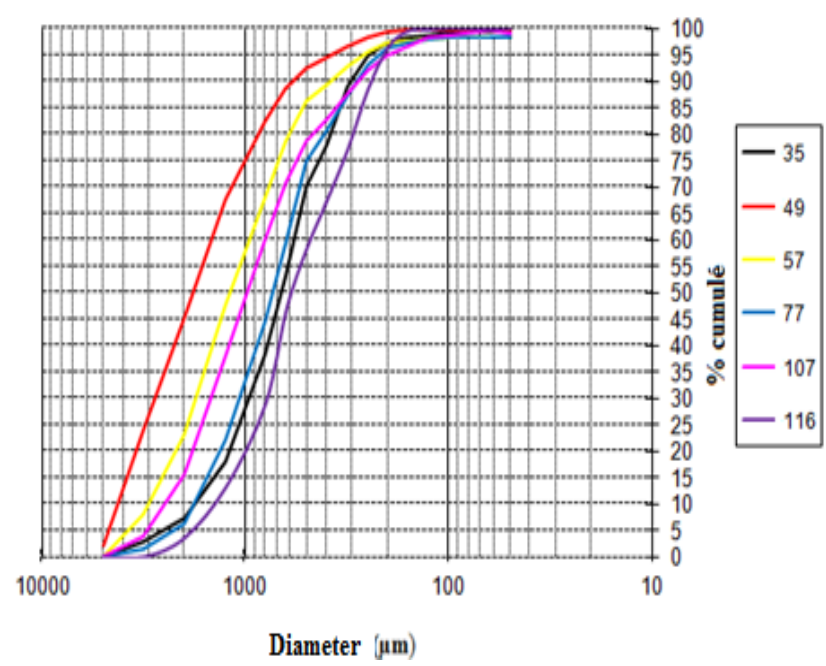

Figure 4: Semi-log cumulative curves of Pakidié sands

\section{- Granulometric parameters}

The calculation of the mean, the standard deviation and the skewness made it possible to characterize the sands of Toupah and Pakidié (Tables 2 and 3). This characterization reveals that the sands are for the most part of coarse size, symmetrical to asymmetrical towards the fine elements and very well classified.

Table 2: Granulometric characteristics of the sands of the Toupah well

\begin{tabular}{|l|l|l|l|l|}
\hline $\begin{array}{l}\text { Depth } \\
(\mathbf{m})\end{array}$ & Mz & So & Sk & Description \\
\hline 35 & 1436,67 & 0,35 & 0,26 & $\begin{array}{l}\text { Coarse sand,well ranked } \\
\text { asymmetry towards the fine } \\
\text { element }\end{array}$ \\
\hline 50 & 2033,33 & 0,34 & 0,14 & $\begin{array}{l}\text { Coarse sand,very well ranked } \\
\text { asymmery towards the fine } \\
\text { element }\end{array}$ \\
\hline 66 & 1283,33 & 0,41 & 0,28 & $\begin{array}{l}\text { Coarse sand,well ranker } \\
\text { asymmery towards the fine } \\
\text { element }\end{array}$ \\
\hline 111 & 1303,33 & 0,38 & 0,15 & $\begin{array}{l}\text { Coarse sand,well ranker } \\
\text { asymmery towards the fine } \\
\text { element }\end{array}$ \\
\hline
\end{tabular}

Table 3: Granulometric characteristics of the sands of the Pakidié well

\begin{tabular}{|c|c|c|c|c|}
\hline $\begin{array}{c}\text { Depth } \\
(\mathbf{m})\end{array}$ & Mz & So & Sk & Description \\
\hline
\end{tabular}




\begin{tabular}{|l|l|l|l|l|}
\hline 40 & 1700 & 0,38 & 0,26 & $\begin{array}{l}\text { Coarse sand,well ranker } \\
\text { asymmery towards the fine } \\
\text { element }\end{array}$ \\
\hline 58 & 1440 & 0,34 & 0,18 & $\begin{array}{l}\text { Coarse sand,very well ranker } \\
\text { asymmery towards the fine } \\
\text { element }\end{array}$ \\
\hline 76 & 866,67 & 0,31 & 0,05 & $\begin{array}{l}\text { Coarse sand,well ranker } \\
\text { asymmery towards the fine } \\
\text { element }\end{array}$ \\
\hline 109 & 1133,33 & 0,35 & 0,16 & $\begin{array}{l}\text { Coarse sand,well ranker } \\
\text { asymmery towards the fine } \\
\text { element }\end{array}$ \\
\hline
\end{tabular}

\section{- Mode of transport of sediments}

The diagram of [17], applied to the soft sediments of the Toupah well and the Pakidie well, shows four (4) populations (P1-P2-P'2-P3). Saltation (74.5\%) is the dominant mode of transport for Toupah Well sediments, while this mode represents $(83 \%)$ the transport of sediments from the Pakidie Well. The coarse sands are transported mainly by thrusting and saltation. The average sands meanwhile are transported by saltation and suspension, while the fine sands by suspension.

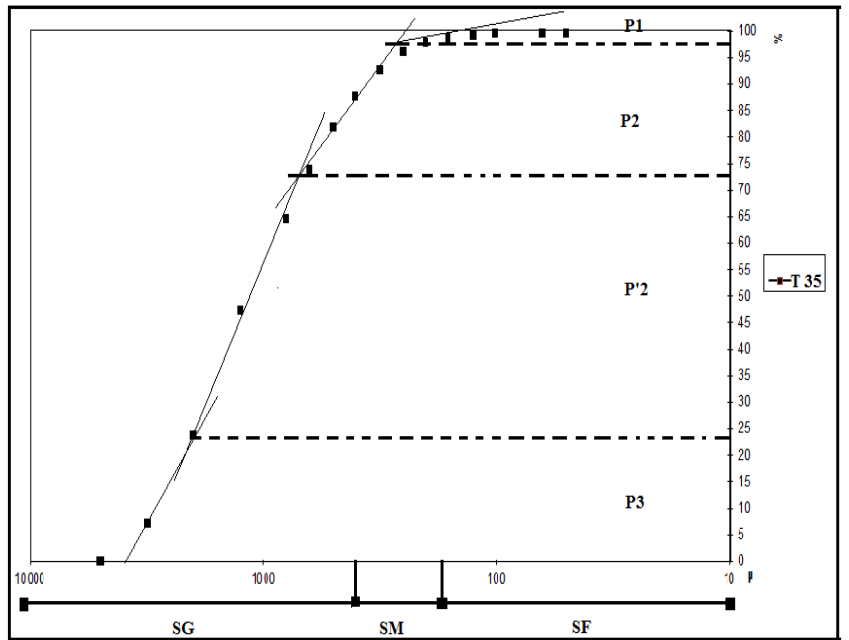

Figure 5: Application of the Visher test to Toupah soft sediments

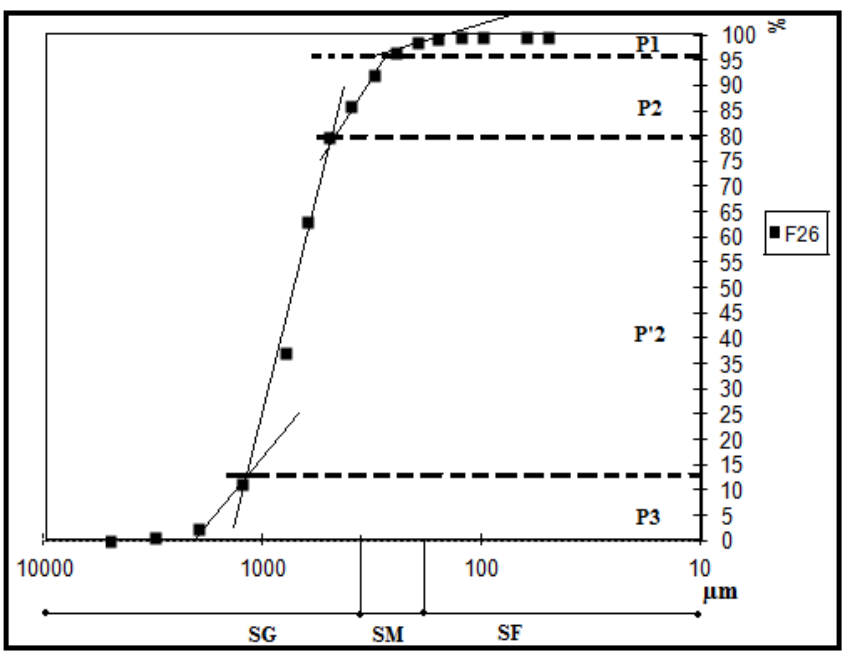

Figure 6: Application of the Visher test to Pakidie soft sediments

\section{- Deposit environments}

The Md / Sk diagram shows that the dispersion is $100 \%$ in the coastal area for both wells. The So / Md diagram also shows that the dispersion is $100 \%$ in the range domain.
Sedimentation was therefore carried out in a marine beach environment where the coastal dunes are formed.
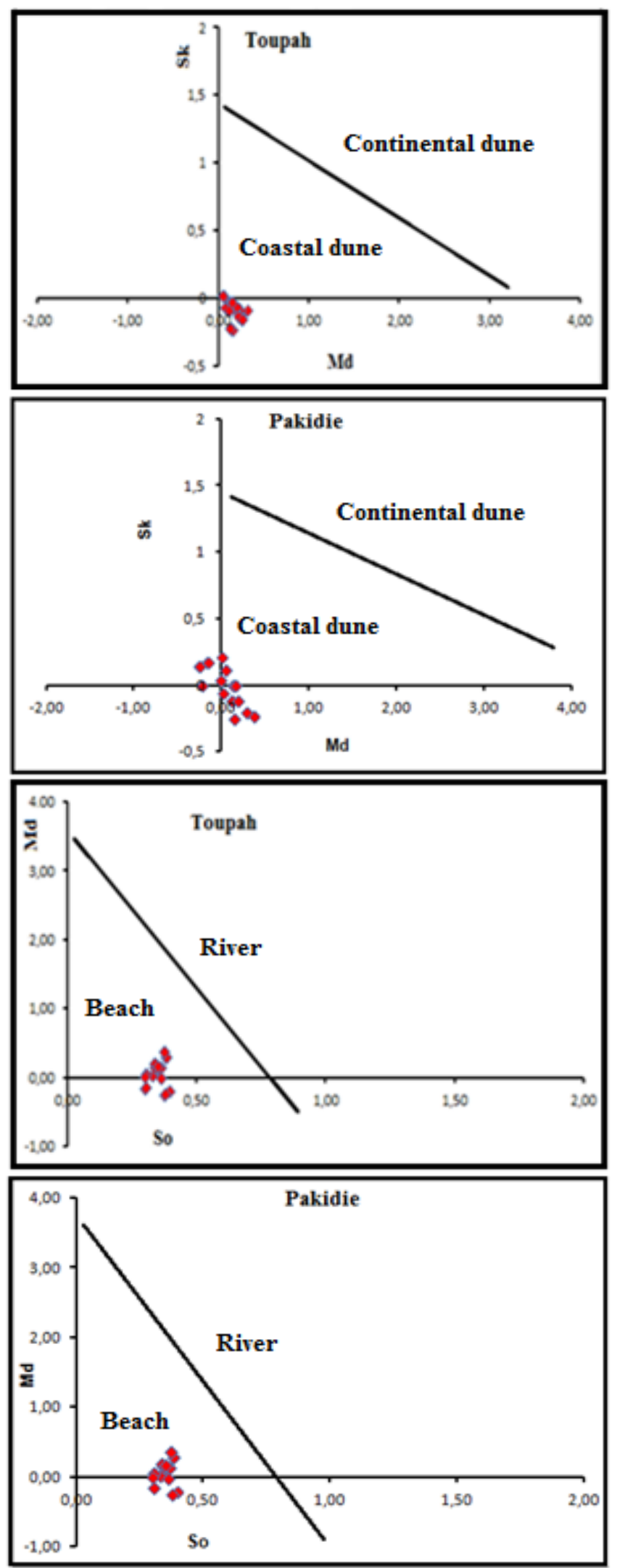

Figure 7: So / Md and Md / Sk diagrams of the sands of Toupah and Pakidie wells

- Morphoscopy of quartz grains

The morphoscopy of the sand grains of the different wells reveals a variation of the shapes of the grains studied. Indeed, in the Toupah well, the sand grains have shapes of rounded 
(42.25\%), sub-rounded (38.50\%), sub-angular (13.5\%) and angular $(5.75 \%)$. They are translucent with yellow, orange to light gray tints (Figure $8 \mathrm{~A}$ ).

The quartz grains of the Pakidie well also have four morphological types of grains. They are rounded $(31.5 \%)$, sub-rounded $(45.5 \%)$, sub-angular $(15.5 \%)$ and angular $(7.5 \%)$. They are translucent with shades of gray to white (Figure 8 B).

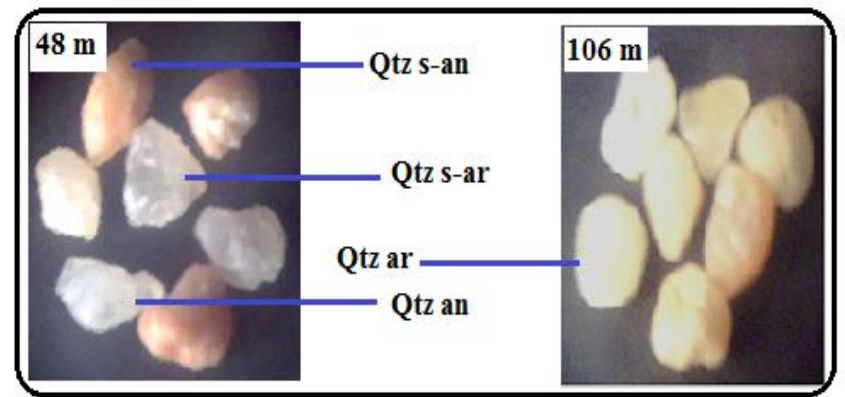

A (Toupah)

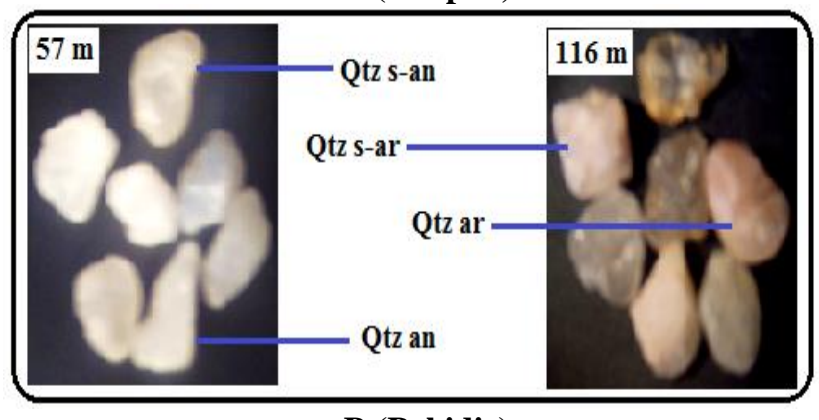

B (Pakidie)

Qtz: quartz, ar: rounded, s-ar: sub-rounded, an: angular, s-an: sub-angular Magnification $400 \mu \mathrm{m}$ x 120

Figure 8: Morphoscopy of quartz grains from Toupah (A) and Pakidie (B) wells

\section{DISCUSSION}

Sedimentologically, all of the sediments analyzed in the two localities are essentially lateritic clays, coarse sands and yellow clays. The sands are coarse to very well classified with asymmetry towards the fine elements. These results are consistent with those of [1] - [20], which indicate that these sands were deposited with very high energy. The hyperbolic facies, allowed to characterize the type of deposit. Thus, according to [21], in [13], the hyperbolic facies indicates a progressive reduction in the strength of the transport agent. This agent, which was initially capable of transporting grains of a certain size, is no longer so because of a reduction in its speed. As a result, he abandons the grain on the spot. For [22] - [2] - [20], this facies indicates well-graded sands in a medium with fine particles evacuation. The test of [16] indicates that the transport of the sediments studied in the two wells is ensured by saltation and by rotation. The sands observed are mostly rounded to sub-rounded and minor to sub-angular to angular. These results are in line with the work of [20], which states that the rounded and sub-rounded shapes evoke a distant clastic source and relatively long transport, while the sub-angular and angular forms reflect a medium of deposit close to the source generating sands. Most of the grains encountered in the different units have a blunted appearance. Thus, sediment transport was carried out in an aqueous medium.

\section{CONCLUSION}

The sedimentological study of the Pakidie and Toupah wells revealed three main facies: clay facies, sandy facies and facies of mixed sediments (clay sands and sandy clays), all covered with a lateritic layer. These two wells have clayey levels of yellowish color.The sands of the Pakidié and Toupah wells are generally coarse, well classified, very well classified and generally asymmetrical towards the fine elements. They present sigmoid type facies translating a free accumulation sedimentation and a saltation transport. The quartz grains are mostly sub-rounded to rounded suggesting a relatively distal supply source while the shiny blunted appearance of the grains confirms their stay in the aquatic environment and their deposition in the shallow marine environment.

\section{REFERENCES}

[1] J.M.K. Gbangbot, Stratigraphic characterization of aquifers of subsurface formations of the Ivory Coast lagoons region. Tertiary Deposition Environment Modeling Trial. Doctoral thesis. Specialty: Marine Geology and Sedimentology. UFR of Earth Sciences and Mining Resources. Felix Houphouet-Boigny University in Earth Sciences (Abidjan, Ivory Coast). 2012, 175p

[2]N.J.P.Yao, Sedimentological, mineralogical, geochemical and biostratigraphic characterization of the Fresco cliffs: region og Grand-Lahou (Ivory Coast). Ph.D Thesis, Univ. F.H.B, Cocody, 2012,187p.

[3] C. Bacchiana, R. Y. Brancart, I. (of) Klasz, O. Legoux \& G. Paradis, Presence of the lower Miocene marine in Abidjan in the "Continental terminal" of the lower Ivory Coast. Micropaleontology Review, 25 (3): 1982, 145-149.

[4] Z.B. Digbehi, Comparative study of the sedimentation of the early stages of the opening of the Atlantic: Gulf of Guinea, Bay of Biscay, sedimentology, biostratigraphy, Thesis PhD, Univ. Pau (France), 1987, $366 \mathrm{p}$.

[5] Z.B. Digbehi, K. Affian, S. World, K. Pothin \& K. Aka, Sedimentological analysis of some facies of the Continental Terminal. Presses Universitaires of Ivory Coast, Bioterre, Interternational Review of. Life and earth sciences. (Volume 2) 2001, No. 1 PP. 71-84.

[6] I. Yace, Initiation to geology. The example of Ivory coast and West Africa. CEDA Publishing, 2002, 183 p.

[7] C. A. Akobe, Characterization of Ivory Coast and Ghana Sandstone (Gulf of Guinea): Deposition Environment, Maturity and Energy Potential (Hydrocarbon Reservoirs) Ph.D Thesis »Abidjan, 2010, 167 p.

[8] F.Y.P. Assalé, S. Mondé, K. Aka, T.Koffi, Y.L.H. Kplohi, J. Able, I. Faea. and H.L. Ombléa, Lithostratigraphic Characterization of the Adiaké Adia 5 and Adia 6 Soundings: Evidence of eustatic movements and influence of glauconites on the physical properties of sand European Scientific Journal, Vol.9, N.17, 2013, pp. 332-349.

[9] F.Y.P. Assalé, Sedimentological, palynological, geochemical and palaeoenvironmental characterization of the formations of the east coast of Côte d'Ivoire. Doctoral Thesis of the University Felix Houphouet Boigny, Abidjan, Ivory Coast, 2013, 361 p.

[10] A.H. Boga, sedimentological and stratigraphic analyzes of sedimentary sequences (Cretaceous-Quaternary) of the eastern part of the sedimentary basin of Ivory Coast. Characterization of detrital deposit processes. Single doctoral thesis of F.H.B. University, Abidjan (Ivory Coast), 2015, $235 \mathrm{p}$.

[11] B. Dibi, Quantitative and qualitative assessment of groundwater resources in the Dabou region. Brief of DEA, University of Cocody, UFR STRM, Abidjan, Ivory Coast, 2002,72 p.

[12] Y.B. Koffi, Contribution to the analysis of the methods of interpretation of pumping tests: case of methods derived from the tea solution (grapho-numerical methods and numerical methods): Application to the Biankouma-Man and Dabou sectors, DEA University of Cocody-Abidjan, Ivory Coast, 2003, 53p

[13] A.C. Kra, F.Y.P. Assalé, N.J.P.Yao, \& K. Aka, Sedimentological and mineralogical characterization of Tertiary-Quaternary formations in 
the region of Anyama in southern Côte d'Ivoire. European Scientific Journal. Flight. 12, No. 3, 2016, pp251-265

[14] R.L. Folk et W.C.Ward, Brazos rivers bar : a study in the significance of grain size parameters. Journ. Sc. Petrol. Tulsa Okla, Vol. 27, $\mathrm{N}^{\circ} 1$, 1957, pp. 325-354

[15] Petit-John, Sedimentary rocks. Edit. Harper and Brothers, New-york, 2nd Edit. 1957, 718 p.

[16] G.S. Visher, Grain size distributions and depositional processes. Journ. Sedim. Petrol., vol. 39, 1969, pp. 1074-1106.

[17] R.J. Moiola \& D.Weiser, Textureal parameters : an evaluation. Journ. Sedim. Petrol. $n^{\circ} 38,1968$, pp 45-53.

[18] H.Chamley, Les milieux de sédimentation. BRGM édition, 1988, 173 p. BRGM 2- 7159-0399-5.

[19]E.Saaidi, Traité de sédimentologie, pétrographie, environnements sédimentaires. Editions Afrique Orient, 1991, 399 p.

[20] K.K. Toé.Bi, N.J.P. Yao, T.M. Késsé, \& Z.B. Digbéhi, Caractérisation Sédimentologique et Hydrodynamique des Formations Sableuses du Miocène Inferieur de la Région d'Eboinda (Sud-Est de la European Scientific Journal June) 2016 édition Vol.14, No.18 ISSN 1857 - 7881 (Print) e - ISSN 1857- 7431

[21] A. Rivière, Méthodes granulométriques, techniques et interprétation, Paris, Masson, 170 p., 12 fig., 16 x 24 cm, 130 FF. Géographie physique et Quaternaire, 32(3), 1977, 289- 290.

[22] H. Saidi, M. Brahim, \& M. Gueddari, Caractérisation granulométrique et minéralogique des sédiments de surface de la Frange littorale Sidi Bou Said-la Goulette. Bull Inst. Natn. Scien. Tech. Mer de Salammbô, vol. 31,2004 pp 97-106

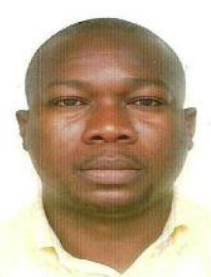

GBANGBOT Jean-Michel Kouadio, Ivorian, Ph.D. in marine geology option sedimentology, UFR Environment of Jean Lorougnon Guédé University (Ivory Coast) 